\title{
INVESTIGATION OF THE RESPIRATION RATE DURING STORAGE OF FRUIT VEGETABLES UNDER THE INFLUENCE OF ABIOTIC FACTORS
}

\author{
Olesia Priss \\ Department of technology of processing and storage of agricultural products \\ Tavria State Agrotechnological University \\ 18 B. Khmelnitskiy ave., Melitopol, Zaporizhia region, Ukraine, 72312 \\ olesyapriss@gmail.com \\ Viktoria Yevlash \\ Department of Chemistry, Microbiology and Nutritional Hygiene \\ Kharkiv State University of Food Technology and Trade \\ 333 Klochkivska str., Kharkiv, Ukraine, 61051 \\ evlashvv@gmail.com \\ Valentina Zhukova \\ Department of Technology of Processing and Storage of Agricultural Products \\ Tavria State Agrotechnological University \\ 18 B. Khmelnitskiy ave., Melitopol, Zaporizhia region, Ukraine, 72312 \\ zhuzhuvf@gmail.com

\section{Sergey Kiurchev} \\ Department of structural materials technology \\ Tavria State Agrotechnological University \\ 18 B. Khmelnitskiy ave., Melitopol, Zaporizhia region, Ukraine, 72312 \\ dec.tgatu@ukr.net
}

\section{Valentyna Verkholantseva}

Department of Processing and Food Production Equipment named after professor F. Yalpachik

Tavria State Agrotechnological University

18 B. Khmelnitskiy ave., Melitopol, Zaporizhia region, Ukraine, 72312

wer.valentina@gmail.com

\section{Iryna Kalugina}

Department of restaurant and health promoting catering

Odessa National Academy of Food Technologies

112 Kanatna str., Odessa, Ukraine, 65039

ik101273@gmail.com

Svetlana Kolesnichenko

Department of restaurant and health promoting catering

Odessa National Academy of Food Technologies

112 Kanatna str., Odessa, Ukraine, 65039

svetlanalk@ukr.net

Alla Salavelis

Department of restaurant and health promoting catering

Odessa National Academy of Food Technologies

112 Kanatna str., Odessa, Ukraine, 65039

onapta@ukr.net 


\author{
Olena Zolovska \\ Department of restaurant and health promoting catering \\ Odessa National Academy of Food Technologies \\ 112 Kanatna str., Odessa, Ukraine, 65039 \\ zolovska.lena@gmail.com
}

Halyna Bandurenko

Department of food technology

Kyiv Cooperative Institute of Business and Law

18 Lomonosova str., Kyiv, Ukraine, 03022

gbandurenko@ukr.net

\begin{abstract}
The aim of the work was to establish the influence of most important abiotic planting factors (temperature, precipitation quantity) on the respiratory rate of fruit vegetables at storage and also a possibility of correction of respiratory metabolism by post-harvest thermal processing by antioxidant compositions. Fruits of cucumbers of the hybrids Masha and Afina, bush pumpkins Kavili and Tamino, sweet pepper of the hybrids Nikita and Hercules, tomato of the varieties Novachok and Rio Grande Original were used for the studies. It was established, that the respiratory rate of pumpkin fruit vegetables is importantly influenced by the variety specificity. The respiratory level of pumpkin vegetables directly correlates with the sum of active temperatures of the period of fruits formation and reversibly - with precipitation and hydrothermal coefficient.

The influence of the variety specificity for nightshade vegetables is leveled, and among meteorological planting conditions the important intense influence on the respiratory rate is realized by the sum of active temperatures of the period of fruits formation and ripening. Precipitation and hydrothermal coefficient have the important influence only on pepper fruits.

It was established, that the use of post-harvest thermal processing by antioxidant compositions results in inhibition of respiratory processes in fruit vegetables at storage.

Keywords: respiratory rate, storage, fruit vegetables, post-harvest thermal processing by antioxidants, abiotic factors.

(C) Olesia Priss, Viktoria Yevlash, Valentina Zhukova, Sergey Kiurchev, Valentyna Verkholantseva, DOI: 10.21303/2504-5695.2017.00494 Iryna Kalugina, Svetlana Kolesnichenko, Alla Salavelis, Olena Zolovska, Halyna Bandurenko
\end{abstract}

\title{
1. Introduction
}

Quality characteristics of fruit vegetables vary widely by years. Even at planting fruits or vegetables of the same variety, their biomechanical composition, storage life and other technological properties change under the influence of changeable abiotic factors [1]. The problem of the influence of abiotic factors on the post-harvest quality of fruit and vegetable products, connected with climate global changes becomes more serious [2]. The most important physiological process in the post-harvest period for fruits and vegetables is respiratory metabolism [3]. Just the respiratory rate reflects a reaction of fruit tissues to stress abiotic factors at planting and storage. The speed of spoilage of fruit vegetable products at storage depends on the level of respiratory processes [3]. For shortening the respiratory activity in the post-harvest period, there were elaborated the series of arrangements: decrease of the storage temperature, preliminary thermal processing, use of ethylene inhibitors and other biologically active substances [4-6]. But the influence of abiotic factors of planting of fruit and vegetable products on physiological processes in the post-harvest period was not taken into account in these researches. So, for prognosticating and correcting storage life of fruit vegetables by the post-harvest thermal processing by antioxidant compositions, their respiratory rate depending on abiotic factors was studied.

\section{Materials and Methods}

The observations were realized during $2005 \ldots 2012$ years. 2 varieties of pumpkin vegetables and 2 varieties of nightshade vegetables were used in the researches. The subject of the research was fruits of cucumbers of the hybrids Masha F1 and Afina F1, bush pumpkins Kavili F1 and Tamino F1 (Fig. 1), sweet pepper Nikita F1 and Hercules F1, tomato Novachok and Rio Grande Original. Vegetables were planted at Southern Zaporizhia region, Ukraine. The region of planting is charac- 
terized by the high heat supply: annual sum of temperatures higher than $10{ }^{\circ} \mathrm{C}$ is $3400 \ldots 3600$. And humidity is the least in Ukraine: the annual hydrothermal coefficient (HTC) is 0,5 ..0,7 units) [7]. So, at planting all fruit vegetables, drop irrigation was used. The spray norm within $30-90 \mathrm{~m}^{3} / \mathrm{ha}$, in separate cases $-110-130 \mathrm{~m}^{3} /$ ha was observed.

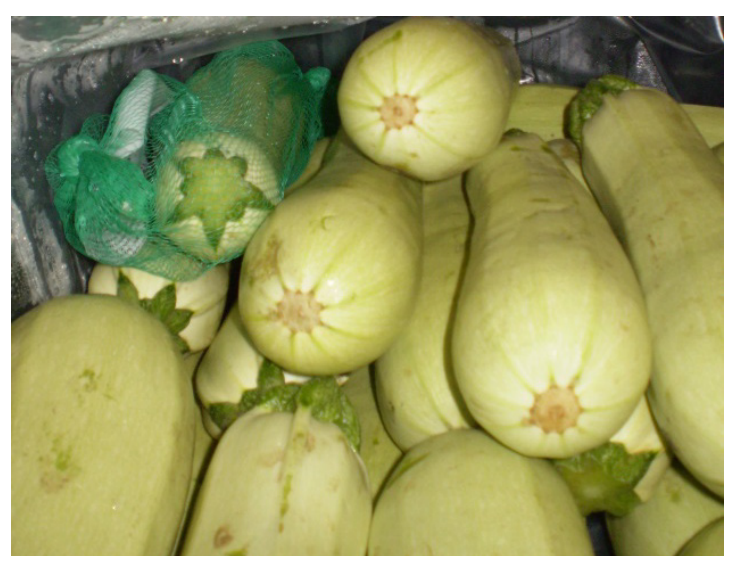

$a$

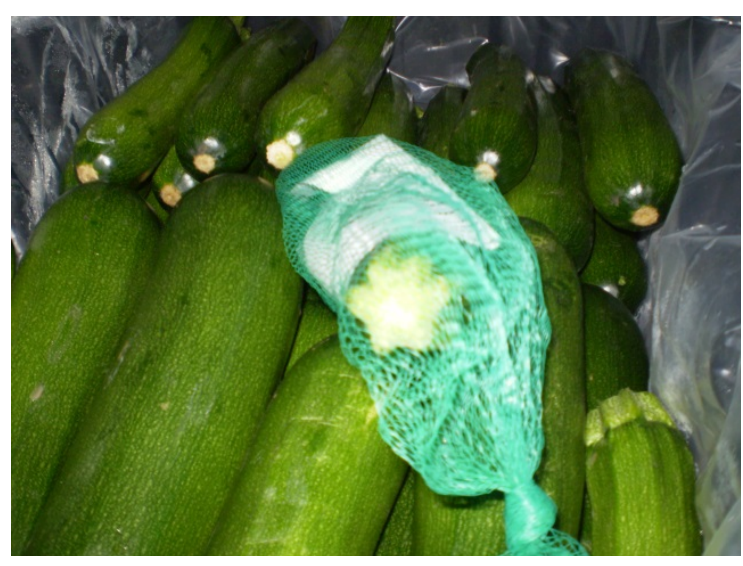

$b$

Fig. 1. Refrigeratory storage of bush pumpkins: $a$ - Kavili F1; $b$ - Tamino F1

Healthy fruits with a pedicle were laid for storage. The maturity degree of pumpkin fruits was determined by size characteristics and the one of nightshade fruits - by coloration. The size of cucumbers - 11-14 cm and of bush pumpkins - 16-21 cm. Tomatoes of the red maturity degree were selected, sweet pepper - at main coloration of no less than $80 \%$ of the surface.

Cucumbers and bush pumpkins were submerged in solutions of antioxidant compositions with the temperature $42{ }^{\circ} \mathrm{C}$ for $10 \mathrm{~min}$. They were stored at $8 \pm 0,5^{\circ} \mathrm{C}$ and relative humidity $95 \pm 1 \%$.

Peppers and tomatoes were submerged in solutions of antioxidant compositions with the temperature $45^{\circ} \mathrm{C}$ for $15 \mathrm{~min}$. Tomatoes were stored at $2 \pm 1{ }^{\circ} \mathrm{C}$, relative humidity of air $90 \pm 3 \%$. Peppers - at $7,0 \pm 0,5^{\circ} \mathrm{C}$ at the relative humidity $95 \pm 1 \%$ (Fig. 2).

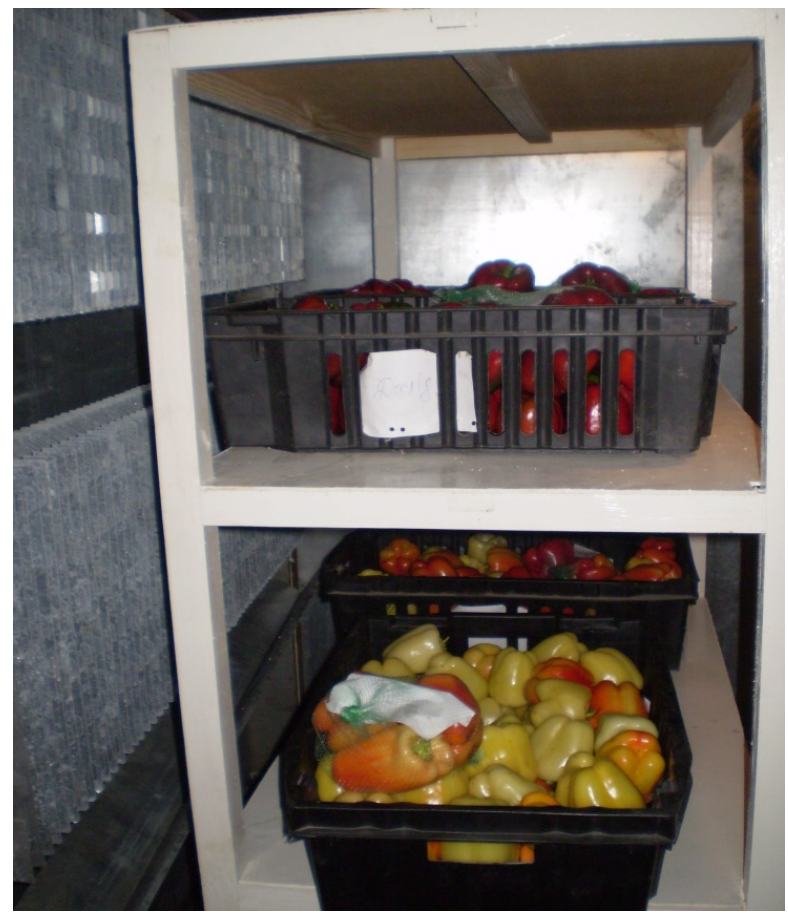

Fig. 2. Refrigeratory storage of sweet pepper Nikita F1 and Hercules F1 
Compositions included the following components: chlorophyllipt (Chl), water extract of horseradish (Hr), ionol (I) and lecithin (L) $[8,9]$. The composition $\mathrm{Chl}+\mathrm{I}+\mathrm{L}$ that differed by concentrations of separate cases was used for cucumbers and bush pumpkins: for cucumbers $0.38 \%$ Chl, $0.036 \%$ I, $4 \% \mathrm{~L}$; for bush pumpkins $-0.75 \% \mathrm{Chl}, 0.048 \% \mathrm{I}, 4 \% \mathrm{~L}$. The composition $\mathrm{Chr}+\mathrm{I}+\mathrm{L}$ was used for tomatoes and pepper. The water extract of horseradish was prepared in ratio of raw material and extractant 1:2. The composition included $4 \%$ of $\mathrm{L}$ and $0.30 \%$ of I for tomatoes and $0,024 \%$ of I for pepper.

Non-processed fruits were used in control variants.

\section{2. Research methods}

According to annual data of the meteorological station of Melitopol city, there were calculated:

- the sum of active temperatures (SAT) higher than $10^{\circ} \mathrm{C}$ of the vegetation period,

- SAT of the period of fruits formation (10 days before harvesting for pumpkins [10], 30 days for pepper [11] and 40 days for tomatoes [12]);

- Selyaninov hydrothermal coefficient (HTC).

According to the same data, there was determined the number of days of the vegetation period that didn't correspond to the biological minimum and maximum for fruit vegetables.

The respiratory rate (RR) in $\mathrm{mg}$ of $\mathrm{CO}_{2} / \mathrm{kg} \times$ hour was determined by Tolmachev's method [13] (Fig. 3).

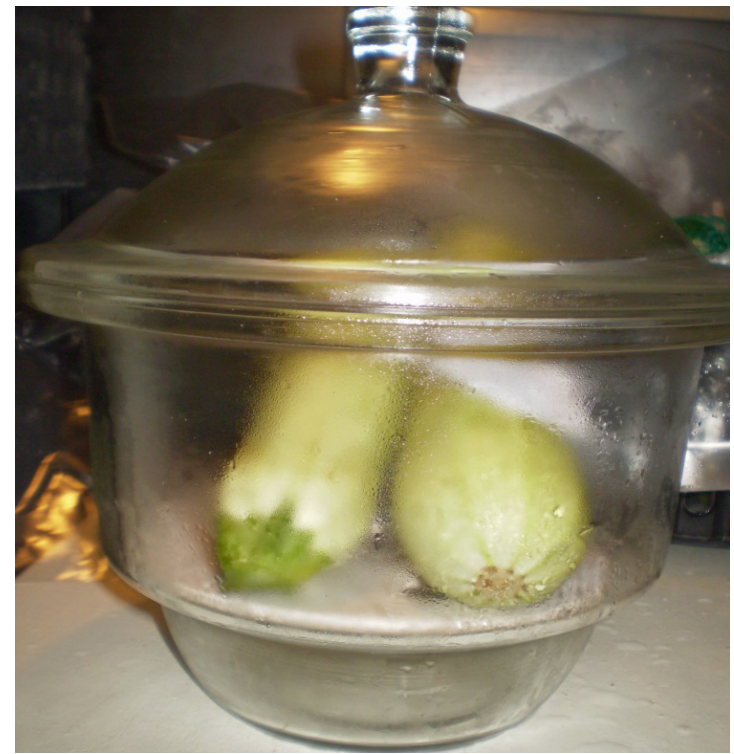

Fig. 3. Determination of vegetables respiratory rate by Tolmachev's method

This method was concluded in absorption of $\mathrm{CO}_{2}$, emitted at fruits respiration, by the alkali solution. The level of $\mathrm{CO}_{2}$ was determined by titration by the solution of hydrochloric acid.

\section{Results}

The veritable variety specification in the respiratory activity of pumpkin fruits was established during the researches (Table 1). Nightshade vegetables are characterized by specific differences of respiratory rate, but variety peculiarities are not expressed.

There were established essential fluctuations of levels of $\mathrm{CO}_{2}$, emitted by fruits, depending on a year of the research. Despite the variety specificity, such regularities were revealed between the respiratory rate and abiotic factors during vegetation. Most close dependencies are typical for SAT of the period of formation of fruits of both botanic families.

The thermal processing by antioxidants had the important inhibiting influence on respiratory activity in fruits of both pumpkin and nightshade vegetables (Fig. 4). 


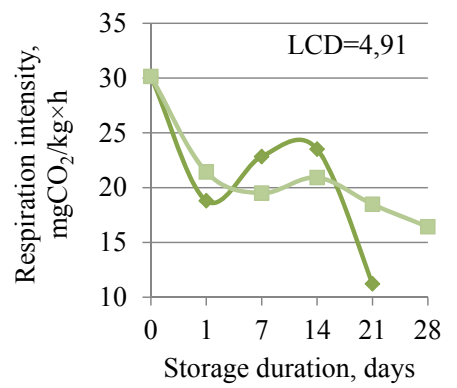

$a$

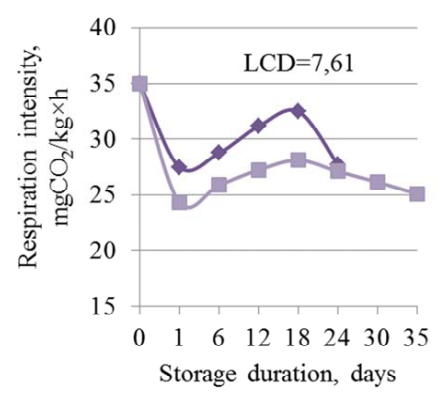

$b$

Fig. 4. Dynamics of respiratory rate: $a$-Afina cucumbers; $b$ - Hercules pepper;

$\neg, \smile-$ control;,----- thermal processing $\mathrm{Chl}+\mathrm{I}+\mathrm{L}$

Table 1

Respiratory rate of nightshade vegetables before storage, $\mathrm{mg}$ of $\mathrm{CO}_{2} / \mathrm{kg} \times$ hour, $\mathrm{n}=3$

\begin{tabular}{cccccc}
\hline \multirow{2}{*}{ Type } & Variety & Respiratory rate, $\mathbf{m g}$ of $\mathbf{C O}_{\mathbf{2}} / \mathbf{k g} \times \mathbf{h o u r}, \mathbf{n}=\mathbf{3}$ & $\mathbf{H I P}_{\mathbf{0}, \mathbf{9}}$ & $\mathbf{V}, \mathbf{\%}$ & $\mathbf{S x}, \mathbf{\%}$ \\
\hline \multirow{2}{*}{ Cucumber } & Afina & 31,73 & 2,35 & 27,51 & 2,44 \\
& Masha & 16,75 & 0,75 & 10,67 & 1,48 \\
\multirow{3}{*}{ Bush pumpkin } & Kavili & 38,68 & 1,72 & 36,40 & 1,46 \\
& Tamino & 58,38 & 1,78 & 16,59 & 1,00 \\
\multirow{2}{*}{ Pepper } & Hercules & 41,49 & 3,03 & 37,64 & 2,40 \\
& Nikita & 46,21 & 3,90 & 37,11 & 2,78 \\
\multirow{2}{*}{ Tomato } & Rio Grande & 10,73 & 13,29 & 10,70 & 1,22 \\
& Novachok & 9,09 & 8,32 & 9,79 & 1,29
\end{tabular}

\section{Conclusions}

The obtained results allow to state that the respiratory rate of pumpkin fruit vegetables is importantly influenced by the variety specificity. The respiratory level of pumpkin vegetables directly correlates with the sum of active temperatures of the period of fruits formation and reversibly - with precipitation and hydrothermal coefficient.

The influence of the variety specificity for nightshade vegetables is leveled, and among meteorological planting conditions the important intense influence on the respiratory rate is realized by the sum of active temperatures of the period of fruits formation and ripening. Precipitation and HTC have the important influence only on pepper fruits.

It was established, that the use of post-harvest thermal processing by antioxidant compositions results in inhibition of respiratory processes in fruit vegetables at storage.

The research results may be useful at making adequate decisions as to planning of arrangements on storage and post-harvest processing of products for decelerating respiratory metabolism. For the deeper understanding of the dependency of respiratory processes in the post-harvest period on abiotic factors, it is necessary to investigate the influence of such stressors as sun radiation, illumination intensity level and other.

\section{References}

[1] Peter, M. A. Hodges, T. M. (2011). Abiotic Stress in Harvested Fruits and Vegetables. Intech, 58. doi: $10.5772 / 22524$

[2] Moretti, C. L., Mattos, L. M., Calbo, A. G., Sargent, S. A. (2010). Climate changes and potential impacts on postharvest quality of fruit and vegetable crops: A review. Food Research International, 43 (7), 1824-1832. doi: 10.1016/j.foodres.2009.10.013 
[3] Saltveit, M. E.; Gross, K. C., Wang, C. Y., Saltveit, M. (Eds.) (2007). Respiratory metabolism. In Agricultural handbook number 66: The commercial storage of fruits, vegetables, and florist and nursery stocks. US Dept. Agr., Washington, DC.

[4] Yang, J., Fu, M., Zhao, Y., Mao, L. (2009). Reduction of Chilling Injury and Ultrastructural Damage in Cherry Tomato Fruits After Hot Water Treatment. Agricultural Sciences in China, 8 (3), 304-310. doi: 10.1016/s1671-2927(08)60213-8

[5] Dhall, R. K. (2013). Advances in Edible Coatings for Fresh Fruits and Vegetables: A Review. Critical Reviews in Food Science and Nutrition, 53 (5), 435-450. doi: 10.1080/10408398.2010.541568

[6] Mohammadi, A., Hashemi, M., Hosseini, S. M. (2016). Postharvest treatment of nanochitosan-based coating loaded with Zataria multiflora essential oil improves antioxidant activity and extends shelf-life of cucumber. Innovative Food Science \& Emerging Technologies, 33, 580-588. doi: 10.1016/j.ifset.2015.10.015

[7] Lyashenko, G. V. (2008). Agroclimatic zoning of Ukraine. Ukrainian Hydrometeorological Journal, 3, 98-108.

[8] Priss, O. P., Prokudina,T. F., Zhukova, V. F. (2009). Substance for the treatment of fruit vegetables before storage. Pat. 41177 Ukraine, IPC A23B 7/00, A23L 3/34.

[9] Priss, O. P., Serdyuk, M. E., Kolyadenko, V. V., Prokudina, T. F., Zhukova, V. F. (2008). Substance for processing berries and fruit vegetables before storage. Pat. 31851 Ukraine, IPC A23B 7/14.

[10] Ahmed, M. (2004). Growth and yield performance of cucumber. International journal of agriculture \& biology, 6 (2), 396-399. Cabi, 230.

[11] Bosland, P. W., Votava, E. J. (2012). Peppers: vegetable and spice capsicums. CPI Group (UK):

[12] Heuvelink, E. (2005). Tomatoes. CABI, 339.

[13] Naichenko, V. M. (2001). Workshop on technology storage and processing of fruits and vegetables with the basics of commodity. Kyiv: FADA LTD, 211. 